UDC $81 / 33$

DOI https://doi.org/10.26661/2414-1135-2020-80-1-38

\title{
THE PHENOMENON OF FEAR FROM THE POINT OF VIEW OF LINGUISTIC RESEARCH
}

\author{
Koliadzhyn O. A. \\ 6th year Student \\ Institute of Computer Sciences and Information Technologies \\ Lviv Polytechnic National University \\ Stepana Bandery str., 12, Lviv, Ukraine \\ orcid.org/0000-0002-4304-7082 \\ koliadzhynolha@gmail.com
}

Key words: linguistic pragmatics, phenomenon of fear, lexicology, linguistic research, intentionality, emotions, semantic, concept.
The article outlines research approaches in modern linguistics to the study of the phenomenon of fear (lexical semantics, cognitology, cognitive syntax), which made it possible to identify a number of unresolved issues and outline ways to overcome them. Since the fear of basic human emotions, which alone has a decisive influence on human existence, is reflected in the minds of all members of the ethnic community, has a significant arsenal of linguistic means of representation. Depending on the type of consciousness that reflects the emotional experience and the sphere of functioning of knowledge, the emotional concept of "fear" is described as naive and scientific. The application of a linguo-pragmatic approach to the analysis of the linguistic expression of the phenomenon of fear is proposed; it is noted that the theoretical and methodological basis of this approach is just being formed; the basic principles and concepts, the involvement of which will allow a more objective analysis of the stipulation of the phenomenon of fear within one or more languages. One of the priority areas of linguistic research within the cognitive-discursive paradigm is to study the relationship between the emotional sphere of human consciousness and the language system used by it in the process of nominativecommunicative activity. Approaches to the study of fragments of the emotional picture of the world are systematized; the definition of the term "emotional concept" is adjusted. It is interpreted as a multilevel poly structural mentallinguistic form, which, on the one hand, is an emotional form of cognition of the world and through experience correlates with thought forms, on the other - a set of elementary meanings, i.e. comprehended by the subject of cognition (mental and other characteristics) a representative of a certain social group (ethnic, professional, etc.) emotions. Subject-object passions in the text form the basis of text creation in the discourse of fear. Subjectivity is the basis of any text of artistic discourse, and in the circumstances of its relation to the discourse of passions, it becomes the basis of text creation. The textual embodiment of subject-object passion relations is a way of constructing a fictional world of horror discourse, where the distinction of subjects of passion is the first stage of actualization of the communicative meaning of "fear", and reference and nomination are strategies of its linguistic embodiment. 


\title{
ФЕНОМЕН СТРАХУ ТА ЙОГО СПОСОБИ ДОСЛІДЖЕННЯ В ЛІНГВІСТИЦІ
}

\author{
Коляджин О. А \\ студентка VI курсу \\ Інститут комп 'ютерних наук та інформаційних технологій \\ Національного університету «Львівська політехніка» \\ вул. Степана Бандери, 12, Львів, Україна \\ orcid.org/0000-0002-4304-7082 \\ koliadzhynolha@gmail.com
}

\author{
Ключові слова: лінгвістична \\ прагматика, явище \\ страху, лінгвістичні \\ дослідження, лексикологія, \\ інтенціональність, емоциї, \\ семантика, кониепт.
}

\begin{abstract}
У статті викладено дослідницькі підходи, що використовуються сучасною лінгвістикоюдля вивчення явища Страх (лексична семантика, когнітологія, когнітивний синтакс). Оскільки страх основний над людськими емоціями, сам по собі має вирішальний вплив на людське існування, відображається у свідомості всіх представників етнічної спільноти, має значний арсенал мовних засобів репрезентації. Це дає змогу виявити низку невирішених проблем та окреслити шляхи їх подолання. Запропоновано застосування лінгво-прагматичних підходів до аналізу мовного вираження явища страху; зазначається, що теоретична й методологічна основа цього підходу лише в стані формування; залучення деяких основних принципів і концепцій дасть змогу більш об'єктивно проаналізувати обумовленість явища страху в одній або декількох мовах. Одним із пріоритетних напрямів лінгвістичних досліджень у рамках когнітивно-дискурсивної парадигми є дослідження взаємозв'язку між емоційною сферою людської свідомості й мовною системою, що використовується нею в процесі номінативно-комунікативної діяльності. Систематизовано підходи до вивчення фрагментів емоційної картини світу; уточнено визначення терміна «емоційне поняття». Систематизовано підходи до вивчення фрагментів емоційної картини світу; уточнено визначення терміна «емоційне поняття». Він трактується як багаторівнева поліструктурна ментально-лінгвістична форма, яка, з одного боку, є емоційною формою пізнання світу й за допомогою досвіду співвідноситься 3 формами мислення, з іншого - сукупністю елементарних значень, тобто осягається суб'єкт пізнання (психічні та інші характеристики), представник певної соціальної групи (етнічної, професійної тощо) емоцій. Суб'єктивність $\epsilon$ основою будь-якого тексту художнього дискурсу, а за обставин іiі відношення до дискурсу пристрастей вона стає основою створення тексту. Текстове втілення відносин пристрасті суб'єкт-об' єкт - це спосіб побудови вигаданого світу дискурсу жахів, де розмежування суб'єктів пристрасті є першим етапом актуалізації комунікативного значення «страху», а посилання й номінація є стратегіями його мовного втілення.
\end{abstract}

Article presents a review of research approaches to the analysis of lingual presentation of fear in modern linguistics (lexical semantics, cognitology, cognitive syntax). The topicality of the range of problems touched within the article comes from the requirement of recent approaches to the studying of fear representation taking under consideration these achievements and puzzles.

The aim of the article is to formulate research project perspectives of applying lingual-pragmatic approach to studying the lingual presentation of fear within the background of conclusions made by representatives of other linguistic trends. It has been mentioned that methodological basis of linguistic pragmatics is being developed now; it's been suggested that basic principles and notions of linguistic pragmatics will allow more objective analysis of verbalizing the phenomenon of fear by means one language or during the contrastive analysis. Finally, it is emphasized that application of lingual-pragmatic approach to studying the lingual presentation of fear does not contradict but enriches the results of researches in this field.

The object of research is to analyze subjectively chosen tokens to denote the phenomenon of fear.

The subject of the research is predicates and noun phrases that have a corresponding lexical meaning. 
The study of the means of expression of emotions in linguistics has long roots and was carried out within different trends, but the complexity of the object of study, as well as various theoretical and methodological principles have not allowed to create a more or less systematic approach to its analysis. Among other things, semantic/ prototypical (A. Vezhbytska, A. Zaliznyak) and metaphorical (N. Arutyunova, O. Wolf, M. Johnson, J. Lakoff, M. Rousseau, L. Petrova) approaches are distinguished as priorities [11]. The study of the linguistic embodiment of the phenomenon of "fear" also takes place within the outlined approaches. Representatives of conceptology, lexicology, semasiology and grammatical semantics joined the study of fear.

The semantic field "fear" within one or several languages was studied by I. Varukha, E. Ioanesyan, G. Petrova, Yu. Skvortsova, V. Stankevich-Ivanova and others. The subject of the research was predicates and noun phrases that have a corresponding lexical meaning. One of the drawbacks of this approach is the lack of coverage of the objective psychological and philosophical components of the very phenomenon of fear. In most works, the imperfection of this approach is recognized, since researchers rely only on dictionary definitions of lexemes, thus losing a certain amount of concepts related to fear, such as anxiety, excitement, etc. or, conversely, involving in the analysis a subjectively chosen number of lexemes to denote the phenomenon of fear. This approach is all the more imperfect when trying to analyze the linguistic specificity of the expression of this emotion in comparative studies, because without a broad culturological and philosophical foundation, national specificity is not distinguished, and only the structural features of languages remain in the field of attention of scientists. Moreover, without a thorough analysis of the psychological component of the phenomenon of fear, the conclusions about the universal features of the washing of this state remain unfounded, although intuitively correct.

The conclusions reached by lexicologists and semasiologists can be summarized as follows:

- the general dominates over the specific, which "can be associated with the general laws of thinking, which determine similar ways of categorizing the world by native speakers" [2 p. 5], the means of lexicalization, respectively, differ, which is reflected, for example, in the number of lexemes: according to I. Baruch's calculations, in English there are 128 representative predicates denoting fear, in French 110, in Russian - 76 [2 p. 11];

- the universality of fear appears, first of all, in the structure of this semantic field. A widely cited idea, cited by the authors in support of this conclusion, is the words of A. Vezhbitska that "fear is caused by the biological nature of man, not culture" $[15$, p. 606]. The number of structural elements of the semantic field "fear" is different - some give three elements (I. Varukha, G. Petrova, L. Petrova, V. Shishkova), others (Yu. Skvortsova) - 15 [2; 8; 9; 11; 14]. These studies do not deny each other, but only bring the complexity of studying the selected object;

- "the standard semantic field " fear" is complex in nature, since it covers procedural, substantive and adjective meanings" [2, p. 11], among which, in our opinion, the expert and causator of emotion are especially important (terms of Yu. Skvortsova);

- each of these parameters has a universal set of sem (meanings), for example, the subject of fear (in terms of researchers, this is the one who feels fear) must necessarily be a living being or "designate one of the attributes of a living being" [8], the reason may be related to the past, present or future time;

- fear has a degree of manifestation (comparable to the intensity of the emotions of A. Greimas and J. Fontania).

A. Badalova, A. Belaya, A. Borisov, A. Butenko, S. Zaikina, A. Levchenko, I. Onishchuk, I. Topolskaya, G. Tyukina, Yu. Yaskevich studied the concept of "fear" using the material of one or several languages and others [1, p. 10]. The kinship of the lexicalsemantic and cognitive approaches in the study of all concepts does not allow us to single out conclusions, they would add to the degree of study of the linguistic embodiment of the phenomenon of fear: the works also emphasize the universality of the concept within the languages under consideration, because the concept is structured according to subjective, attributive and predicate components, this emotion is reflected in the concept gradually; its shades are tied to the time of experiencing the emotion; the authors also point to national specificity in quantitative indicators of lexemes expressing the FEAR concept.

Several works are devoted to distinguishing between fear and related or accompanying emotions (for example, fear/anxiety, fear/disgust), comparative analysis is mainly aimed at finding a solution to the problem of equivalence of lexical units, favorably distinguishes the cognitive approach. Fear becomes an organic component of the studied concepts associated with various mythical creatures, for example, DEMON, VAMPIRE and others, where observations about the attributes of these mythical creatures that cause fear, immediately or other complex emotions are successfully combined (for example, N. Harutyunyan, I. Onischuk) (Harutyunyan 2016; Onischuk 2006). For our study, this aspect is especially important, because most scientists combine the cause of fear and the subject that caused it, but we are trying to separate the causal relationships of subjects from the attributes of the source of fear and prove that only observation of a mythical malicious 
creature cannot be the cause of fear, that and the texts testify. According to I. Onischuk, in modern literature the concept of VAMPIR is ambivalent in its emotive coloring, in contrast to more ancient texts, where it was extremely negative. I. Onyschuk's work is an example of the fact that the ideas generated by the study of fear, do not fit within the limits of cognitology, and the author from time to time speaks of communication within the text, which leads her to valuable conclusions about the structure of thriller novels and types of narrators, as well as the means of "inducing negative emotions by the author" [10].

The most reasoned study of the concept of "fear" within the framework of conceptology and comparative historical linguistics is considered the dissertation of S. Zaikina, where the author logically and consistently embodies the idea of objective comparison of this concept in two languages and first rooted its understanding on the psychological, philosophical and social foundations of experiencing the phenomenon of fear ... Thus, S. Zaikina creates a theoretical basis for comparing and highlighting general and nationally-specific features of the FEAR concept, "filling $<\ldots>$ the conceptual framework with means of nomination and description, denoting qualities and signs of fear that are important for every linguistic culture" $[4$, p. 60].

Results. Scientific searches of cognitologists direct their interest in the formation and functioning of the FEAR concept not only in language/languages in general, that is, on vocabulary material, but also within whole types of texts, as, for example, I. Onischuk or M. Nikitin, who studied the thriller novel and the urban novel, respectively. If for I. Onischuk the texts of the novels became only a source of illustrative material, then M. Nikitin, substantiating the originality of the urban legend genre against the background of folklore and relying on the everyday mass idea of fear as the closest to reflection in legends ("the base of a stereotypical scenario of an urban legend" [6]), analyzes the genre specificity of the FEAR concept. Within the framework of the studied genre, the FEAR concept, according to his conclusion, is realized in 8 scenarios: "These urban legends reflect the stereotypical thinking of a person, which leads to the creation of typical scenarios" [6, p. 100], each of them from the point of view of psychology reflects certain phobias a person, for example, xenophobia, fear of open or confined spaces, fear of the road and others. According to the scientist, "an urban legend is a text with a certain intention. This didactic workshop distracts a person from the threat. We believe that fear becomes the concept that organizes the urban legend, which is revealed at all its levels" [6, p. 97]. This conclusion is close to our statement about the basic communicative meaning of the whole text and its impact on text formation and text perception. We also consider the fundamental statement to be valuable for the objectivity of the analysis: "The essence of the cognitive approach when studying a group of words with the general meaning of "fear" is that a synthesis of the linguistic research itself takes place with knowledge about the realities of the surrounding reality, which are indicated by lexical units" [6, p. 99] and "The cultural component of the relationship, which causes a feeling of fear, cannot go unnoticed" [6, p. 98].

Summarizing the study of fear within the cognitive approach, we note that:

- the conclusions of the cognitologist to a certain extent repeat the conclusions of lexicologists and semasiologists, which indicates the objectivity of the results and their relevance for further analysis of the phenomenon of fear;

- the study of the phenomenon of fear is possible and requires the involvement of related concepts and meanings (concepts in the cognitive dimension) for a more objective and thorough study;

- cognitologists focused on the extralinguistic factors that influence the formation and functioning of the FEAR concept in certain linguistic cultures;

- cognitologists first drew attention to the organizing nature of the idea of fear in the process of text formation;

- limited possibilities of the cognitive approach in an organic way indicates the need to apply a communicative view of the washing away of fear, that is, linguistic pragmatics.

The phenomenon of fear did not become an object of research in the course of studying the textual category of emotivity, although various textual categories, and emotiveness in particular, are of interest to many researchers (V. Bolotov, A. Glushchenko, S. Gladio, S. Ionova and others) (Bolotov 1981; Glushchenko 2012; Gladio 2000; Ionova 1998). Certain observations of researchers of emotiveness are taken into account in this work, for example, the differences between the nominative-descriptive and associative-descriptive strategies for the formation of the emotive field of the text [7, p. 168].

Conclusions from the legacy of linguists who have made efforts to study the washing of fear in one or more languages is that without involving the results of related humanitarian disciplines in the analysis of this phenomenon, an objective anthropocentric approach is impossible, the more unreliable the consequences of comparison within two or more languages will be. The study of the verbalization of the phenomenon of fear has shown that the general dominates over the specific and the universal over the national. The structure of the concept of "fear" (concept or LSP) is articulated and open, which allows us to speak about combinatorics and a combination of meanings. There are three basic members in this structure - the subject, fear and the cause of fear - the event. The field of 
fear is not limited in expression to lexemes, phrases or phraseological units, but can be explicated by sentences and whole texts, where (and here opinions differ) either affects the structure of the text, or the speaker chooses those patterns that already exist in the language.

The perspective of this study are obvious, because, first, the study of texts with other communicative meanings, such as terror, will be promising; secondly, the communicative meaning of "fear" may not be the main in texts selected on a communicative basis, and to accompany the communicative meanings in the texts of other intentional orientation.

\section{BIBLIOGRAPHY}

1. Бацевич Ф.С. Нариси з лінгвістичної прагматики : монографія. Львів, 2010. 336 с.

2. Варуха И.В. Предикаты страха в английском, русском и французском языках. Уфа, 2012. $21 \mathrm{c}$.

3. Варуха И.В. Структура внутренней формы номинации (на примере семантического поля «страх» в английском, русском и французском языках). Коммуникативно-функциональное описание языка / ред. В.М. Калимуллина. Уфа, 2011. С. 21-23.

4. Зайкина С.В. Эмоциональный концепт «страх» в английской и русской лингвокультурах: сопоставительный аспект. Волгоград, 2004. 24 c.

5. Ковалёва Л.М. Сентенциональное поле как объект когнитивного исследования. Когнитивные категории в синтаксисе. Иркутск, 2009. С. 105-125.

6. Никитин М.В. Реализация концепта «страх» в сценариях городской легенды. Челябинск, 2002. $196 \mathrm{c}$.

7. Парасин Н.Д. Стратегии перцептивного формирования эмоционального поля текста (на материале поэзии Т. Шевченко). Тамбов, 2014. C. $167-171$.

8. Петрова Г.В. Семантическое поле слова «страх» в русском и португальском языках. Древняя и новая Романия. Москва, 2016. С. $502-520$.

9. Петрова Л.Н. Языковые средства выражения эмоций в английском языке. URL: http:/ nauka-dialog.ru/arxiv/2017/nauchnyij-dialog2017-6/10-02-00-yazyikoznanie-/-linguistics/ yazyikovyie-sredstva-vyirazheniya-emoczij-vanglijskomyazyike.html.

10. Онищук I.Ю. Емоціогенність концепту вампір в англійській мові й мовленні. Одеса, 2006. 21 с.

11. Скворцова Ю.С. Семантика страха и средства ее вербализации в русском и французском языках. URL: http://www.dialog-21.ru/digests/ dialog2006/materials/html/Skvortsova.htm.
12. Сусов И.П. Лингвистическая прагматика. Винница, 272 с.

13. Шишкова В.А. Сентенциональное поле страха в немецком языке. URL: http://journals.tsu.ru/ uploads/import/167/files/16-078.pdf.

14. Шишкова В.А. Прототипические и непрототипические конструкции с предикатом ANGST HABEN. URL: http://www.nsu.ru/ xmlui/ bitstream/handle/nsu/2403/10.pdf.

15. Wierzbicka A. Emotions across languages and cultures: diversity and universals. Cambridge, 1999. $349 \mathrm{p}$.

\section{REFERENCES}

1. Batsevych F.S. (2010) Essays on linguistic pragmatics [monograph] [Narysy Z Linhvistychnoi Prahmatyky Monohrafiia]. Lviv, pp. 336.

2. Varuha I. V. (2012) Fear predicates in English, Russian and French [Predikaty straha v anglijskom, russkom i francuzskom jazykah]. Ufa, pp. 21.

3. Varuha I. V. (2011) The structure of the internal form of the nomination (on the example of the semantic field "fear" in English, Russian and French). Communicative-functional description of the language [Struktura vnutrennej formy nominacii (na primere semanticheskogo polja «strah» v anglijskom, russkom i francuzskom jazykah)]. Kommunikativno-funkcional'noe opisanie jazyka. / red. V.M. Kalimullina. Ufa, pp. 21-23.

4. Zajkina S. V. (2004) Emotional Concept "Fear" in English and Russian Linguocultures: A Comparative Aspect [Jemocional'nyj koncept «strah» v anglijskoj i russkoj lingvokul'turah: sopostavitel'nyj aspekt]. Volgograd, pp. 24.

5. Kovaljova L. M. (2009) Sentential field as an object of cognitive research. Cognitive categories in syntax [Sentencional'noe pole kak objekt kognitivnogo issledovanija. Kognitivnye kategorii v sintaksise]. Irkutsk, pp. 105-125.

6. Nikitin M. V. (2002) Implementation of the concept "fear" in the scenarios of the urban legend [Realizacija koncepta «strah»v scenarijah gorodskoj le-gendy]. Cheljabinsk, pp. 196.

7. Parasin N. D. (2014) Strategies for the perceptual formation of the emotional field of the text (based on the poetry of T. Shevchenko) [Strategii perceptivnogo formirovanija jemocional'nogo polja teksta (na materiale pojezii T. Shevchenko)]. Tambov, pp. 167-171.

8. Petrova G. V. (2016) Semantic field of the word "fear" in Russian and Portuguese. Ancient and new Romania [Semanticheskoe pole slova «strah»" v russkom i portugal'skom jazykah. Drevnjaja i novaja Romanija]. Moskva, pp. 502-520.

9. Petrova L. N. Linguistic means of expressing emotions in English [Jazykovye sredstva vyrazhenija 
jemocij $\mathrm{v}$ anglijskom jazyke]. Retrieved from: (http://nauka-dialog.ru/arxiv/2017/nauchnyij-dialog-2017-6/10-02-00-yazyikoznanie-/linguistics/yazyikovyie-sredstva-vyirazheniya-emoczij-v-anglijskomyazyike.html) (accessed (11 July 2020)).

10. Onishhuk I. Ju. (2006) Emotionality of the vampire concept in English and speech [Emociogennist' konceptu vampir $\mathrm{v}$ anglijs'kij movi $\mathrm{j}$ movlenni]. Odesa, pp. 21.

11. Skvorcova Ju.S. Semantics of fear and means of its verbalization in Russian and French [Semantika straha i sredstva ee verbalizacii v russkom i francuzskom jazykah]. Retrieved from: (http:// www.dialog-21.ru/digests/dialog2006/materials/ html/Skvortsova.htm) (accessed (13 May 2020)).
12. Susov I. P. (2009) Linguistic pragmatics [Lingvisticheskaja pragmatika]. Vinnica, pp. 272.

13. Shishkova V. A. Sentential field of fear in German [Sentencional'noe pole straha $\mathrm{v}$ nemeckom jazyke]. Retrieved from: (http://journals.tsu.ru/ uploads/import/167/files/16-078.pdf) (accessed (22 May 2020)).

14. Shishkova V. A. Prototypic and non-prototypic constructs with predicate ANGST HABEN [Prototipicheskie i neprototipicheskie konstrukcii $\mathrm{s}$ predikatom ANGST HABEN]. Retrieved from: (http://www.nsu.ru/xmlui/ bitstream/handle/ nsu/2403/10.pdf) (accessed (9 June 2020)).

15. Wierzbicka A. (1999) Emotions across languages and cultures: diversity and universals. Cambridge, pp. 349. 